\title{
Political Constitutionalism under a Culture of Legalism: Case Studies from Ireland
}

\author{
Conor Casey* and Eoin Daly**
}

\begin{abstract}
Political constitutionalism understood in terms of autonomy of political judgement rather than allocation of powers - Irish case studies as example - Judicial doctrines recognise political discretion concerning rights - However, legalism or legal constitutionalism arises within the sphere of political judgement itself - Legal constitutionalism restricts political autonomy epistemically as well as institutionally
\end{abstract}

\section{INTRODUCTION}

In the autumn and winter of 2020, a major controversy on judicial impeachment in Ireland invited reflection on the meaning and significance of political constitutionalism within what we will call a 'culture of legalism'. This episode, along with others we will discuss, illustrates a type of legal constitutionalism (or simply 'legalism') that is expressed, we argue, not as a set of institutional constraints, but rather, sociologically and epistemically speaking, as a certain conceptualisation of political judgement itself.

In August 2020, in short, a Supreme Court judge was embroiled in major controversy following his attendance at an infamous golf-society dinner that was allegedly organised in contravention of legislative restrictions relating to the Covid-19 pandemic. ${ }^{1}$ Following an internal judicial inquiry which led to

*Lecturer in Law, University of Liverpool School of Law \& Social Justice.

${ }^{* *}$ Lecturer in Law, National University of Ireland, Galway School of Law.

${ }^{1} S$. Harrison, 'GolfGate: Séamus Woulfe "should resign", says Irish chief justice' $B B C$ News, 10 November 2020, 〈https://www.bbc.com/news/uk-northern-ireland-54885213〉, visited 16 June 2021.

European Constitutional Law Review, 17: 202-231, 2021

(C) The Author(s), 2021. Published by Cambridge University Press on behalf of European Constitutional Law Review. This is an Open Access article, distributed under the terms of the Creative Commons Attribution licence (http://creativecommons.org/licenses/by/4.0/), which permits unrestricted re-use, distribution, and reproduction in any medium, provided the original work is properly cited. doi: $10.1017 / S 1574019621000183$ 
the Chief Justice publicly calling - unheeded - for Justice Séamus Woulfe's resignation, the question of judicial impeachment by the Oireachtas, the Irish parliament, was raised. While impeachment remained the only formal legal mechanism for judicial discipline at this time, the Government quickly rejected the idea, citing the 'high constitutional standard' required to establish 'stated misbehaviour' - despite this constitutional standard for removal of judges being defined nowhere in case law, in statute, or in the Constitution itself.

In this article, we consider this episode as a starting point to try to better understand the relationship between political and legal constitutionalism, and in particular the forms these assume, beyond mere institutional configurations, in specific political communities. Legal constitutionalism, in contrast with political constitutionalism, is normally understood not only as reflecting certain political values and commitments - particularly a commitment to the primacy of rights - but also as being manifested specifically in particular institutional structures or allocations of institutional power, most obviously in courts being given the 'final say' in matters of constitutional interpretation. ${ }^{2}$ And political constitutionalism, conversely, is typically conceptualised in terms of an absence of formal legal restraint on democratic political power as expressed, usually, by the elected legislature. ${ }^{3}$

However, we argue that the judicial impeachment episode in Ireland, considered in tandem with wider aspects of its legal and political culture, illustrates a different aspect or dimension of legal constitutionalism. Legal constitutionalism, we argue, can be usefully understood as being manifested not only in constitutional allocations of decisional power, but also as having important epistemic and even social/sociological dimensions. While political constitutionalism can be conceptualised and justified in terms of the relative autonomy of political judgement against juristic constraint, we argue this autonomy can be constrained not only by the formal institutional powers assigned to constitutional courts and others, but also by constitutional cultures that see aspects of political judgement formatted within a culture or habitus of 'legalism' - that is to say, a tendency, in particular, to eschew any understanding of political judgement as being exercised prudentially or contingently, in the absence of pre-existing legal norms; and which resists the notion of political actors legitimately making independent interpretations of constitutional norms. Thus legal constitutionalism is expressed partly in the conceptualisations and self-conceptualisations of political actors.

This is reflected, we argue, in the fact that while the relevant constitutional doctrines in Ireland acknowledged a broad formal autonomy for the Oireachtas

${ }^{2} \mathrm{~T}$. Hickey, 'Judges and the Idea of 'Principle' in Constitutional Adjudication', in L. Cahillane et al. (eds.) Judges, Politics and the Irish Constitution (Manchester University Press 2017) at p. 64-65.

${ }^{3}$ R. Bellamy, 'Political Constitutionalism and the Human Rights Act', 9 International Journal of Constitutional Law (2011) p. 86 at p. 89. 
to itself define the substance of 'stated misbehaviour - 'to legislate-in action', so to speak - the relevant political actors tended to conceptualise the question with an assumption of prior legal and normative constraint. We attempt to link this to a wider 'culture of legalism' that may prevail even within a constitutional framework that acknowledges a wide formal breadth of political autonomy. We suggest that this aspect of political and legal constitutionalism should be taken more seriously partly because, we argue, the appeal of political constitutionalism lies largely in its connection with political freedom understood as the autonomy of political judgement. In turn, an autonomy of political judgement cannot be substantively realised under a dominant culture or ideology of legalism.

This article is structured under three headings. In the first section, we describe the controversial events leading to a mooted parliamentary impeachment of Justice Séamus Woulfe. While the Government refused to support impeachment based on what it called the 'deliberately high constitutional standard' required, we argue, to the contrary, that in the absence of a defined constitutional standard for 'stated misbehaviour', the Irish parliament would have been free, based on the relevant constitutional doctrines, to make a sui generis judgement on the judge's conduct in the absence of established legal norms concerning judicial misconduct.

In the second section, we argue that this evasion or denial of political judgement, in the Woulfe episode, illustrates a wider, seemingly paradoxical pattern in Ireland - a political culture of legalism predominating within a constitutional framework whose jurisprudence officially acknowledges a relatively wide autonomy for political judgement. Through offering several additional case studies we show that 'legalism' or legal constitutionalism finds expression as much in the epistemic constraints upon political judgement - in the evasive or constrained discourse of political judgement itself - as in any formal allocation of powers.

In the third section, we outline what our argument means for debates over legal and political constitutionalism more generally. We argue that if political constitutionalism means anything, it must preserve a sphere of relative autonomy for political judgement, as a means of preserving political freedom and the capacity of the State to exercise creative, discretionary action for compelling normative ends like public welfare or the common good. We argue that this relative autonomy of political judgement can be compromised in a discursive or epistemic, as much as in an institutional, sense.

\section{Parliamentary Removal of JUdges in IRELAND: AN EVASION OF POLITICAL JUDGEMENT?}

The controversy leading up to an unprecedented mooting of a Supreme Court judge being impeached by the Irish parliament arose in the very peculiar 
circumstances of legislative restrictions in effect during the Covid-19 pandemic. The Oireachtas Golf Society organised a Gala golfing tournament during a relative easing of restrictions in the summer of 2020. This comprised a dinner and prizegiving at which 80 persons were allegedly present in a (partitioned) ballroom, despite there being a limit of 50 persons permitted at indoor gatherings under the regulatory provisions then in effect. Furthermore, there had been an announced tightening of restrictions including a limit of six persons at indoor gatherings, which was due to come into effect in the days following the event, although was not yet in force at the relevant time. ${ }^{4}$

'Golfgate' generated immediate and enormous public controversy and led to the speedy resignation of the Minister for Agriculture and some time later, of the Irish EU commissioner, Phil Hogan - with media coverage focusing partly on the anger expressed by those who had forsaken funerals, weddings and other large gatherings during the pandemic. ${ }^{5}$

The attendance at the event of Supreme Court Judge, Mr. Justice Seamus Woulfe, generated a more protracted and multifaceted controversy, arising in part from his refusal to resign as a result of his attendance. In the absence of a statutory process for investigating alleged judicial misconduct, or indeed, of guidelines defining such misconduct, the Chief Justice, Mr. Justice Frank Clarke, initiated an internal non-statutory inquiry conducted by a retired Supreme Court judge, Ms. Justice Susan Denham. Following an interview with Justice Woulfe, Justice Denham's report on the matter concluded that a call for resignation would be 'disproportionate' in the circumstances. ${ }^{6}$

However, further public controversy arose from the publication of the transcript of the interview, which for many commentators, revealed a dismissive attitude on the part of Justice Woulfe towards the seriousness of the matter. ${ }^{7}$ Matters came to a head in November 2020, when the Chief Justice made an unpreceded public intervention, publishing a statement in which he let it be

${ }^{4} \mathrm{~A}$. Moore and P. Hosford, 'Minister apologises for attendance at golf event in breach of health guidelines' Irish Examiner, 20 August 2020, 〈https://www.irishexaminer.com/news/arid-40035389. html $\rangle$, visited 16 June 2021.

${ }^{5 ‘}$ EU trade commissioner Phil Hogan resigns over "Covid breach”', BBC News, 26 August 2020, 〈https://www.bbc.com/news/world-europe-53923052〉, visited 16 June 2021.

${ }^{6 r}$ Statement, Report and Appendices - Review By Ms Justice Denham', 1 October 2020, $\langle$ https://judicialcouncil.ie/news/statement-and-report-arising-from-review-by-ms-justice-denham/〉, visited 16 June 2021

${ }^{7}$ Letters in full: What Chief Justice said to Mr Justice Seamus Woulfe over golfgate dinner and his reply', Irish Times, 9 November 2020 /https:/www.irishtimes.com/news/crime-and-law/ letters-in-full-what-chief-justice-said-to-mr-justice-seamus-woulfe-over-golfgate-dinner-and-his-reply$1.4404867\rangle$, visited 16 June 2021. 
known that be believed Justice Woulfe should resign, and furthermore, indicating that this view was shared by all the other members of the Court. ${ }^{8}$

This intervention led to an unprecedented crisis at the Court, which otherwise has had quite a 'collegiate' style and history. ${ }^{9}$ The impasse had arisen in part from the 'all or nothing' provision for judicial discipline in Irish law, which had arguably forced the Chief Justice into an improvised and semi-informal resolution process that culminated so farcically. The Judicial Council Act 2019 provides for a structured judicial-discipline system for the first time in the history of the State but had not yet been commenced at the time of the relevant events. In the alternative, the only formal legal provision for dealing with judicial misconduct is the provision, in Article 35 of the Constitution, for the removal of judges by a resolution of both Houses of the Oireachtas for 'stated misbehaviour'. ${ }^{10}$

This anomaly, along with the possible appearance of impunity in the absence of resignation, led to some political discussion of the possibility of impeachment of Justice Woulfe by the Oireachtas. This discussion was rather limited and muted, and culminated in an attempt by two far-left TDs (members of Dáil Éireann, the lower House), to move a motion for Justice Woulfe's removal. ${ }^{11}$

This attempt to move an 'impeachment' ${ }^{12}$ motion failed amidst a procedural row in Dáil Éireann, and the matter did not proceed to a Dáil vote - with little evidence of an appetite to proceed in most opposition as well as Government parties. ${ }^{13}$ What is critical, however, are the reasons given by the Government for rejecting the idea of judicial impeachment in these circumstances. ${ }^{14}$ Specifically, the Taoiseach Micheál Martin referred, in Dáil debates, to what

${ }^{8} \mathrm{M}$. Carolan and P. Leahy, 'Government seeks legal advice over standoff between judges', Irish Times, 9 November 2020 〈https://www.irishtimes.com/news/crime-and-law/government-seekslegal-advice-over-stand-off-between-judges-1.4404872 $\rangle$, visited 16 June 2021.

${ }^{9}$ See generally R. Mac Cormaic, The Supreme Court (Penguin 2016).

${ }^{10}$ Art. 35.4.1 provides that a 'judge of the Supreme Court, the Court of Appeal, or the High Court shall not be removed from office except for stated misbehaviour or incapacity, and then only upon resolutions passed by Dáil Éireann and by Seanad Éireann calling for his removal'.

${ }^{11}$ M. O'Halloran and P. Leahy, 'Motion seeking to impeach Woulfe to be moved in Dáil this week', Irish Times, 23 November 2020 〈https://www.irishtimes.com/news/politics/motion-seekingto-impeach-woulfe-to-be-moved-in-d\%C3\%A1il-this-week-1.4416238〉, visited 16 June 2021.

${ }^{12}$ The Constitution uses the term 'remove' rather than 'impeach', but the latter has been used in public discourse on the issue.

${ }^{13} \mathrm{M}$. O'Halloran, 'Dáil row over TD's call for debate to initiate Woulfe impeachment proceedings', Irish Times, 1 December 2020, 〈https://www.irishtimes.com/news/politics/d\%C3\%A1il-rowover-td-s-call-for-debate-to-initiate-woulfe-impeachment-proceedings-1.4424897〉, visited 16 June 2021.

${ }^{14} \mathrm{~A}$. Moore et al., 'Woulfe row: Taoiseach confirms 'no further steps' after 'very careful consideration', Irish Examiner, 17 November 2020, 〈https://www.irishexaminer.com/news/arid40083893.html), visited 16 June 2021. 
he considered to be the 'important distinction between a resignation' and the 'deliberately high standard' set by the constitutional threshold of 'stated misbehaviour'. ${ }^{15}$ This was arguably a curious approach to adopt, on the face of things, both because the Constitution does not define 'stated misbehaviour', on the one hand, and because of the lack of any legal or political precedent in Ireland giving any such definition, on the other. In fact, the only constitutional case law concerning judicial impeachment strongly suggests that the Oireachtas would have constitutionally enjoyed scope to define 'stated misbehaviour' in a highly unstructured and case-specific way, and, relatedly, that the Supreme Court would understand the separation of powers as obliging it to give a wide - albeit not an unlimited - berth to the national parliament in defining this term in specific cases.

The only ruling dealing with this question is Curtin v Dáil Éireann. ${ }^{16}$ Judge Curtin, a judge of the Circuit Court, was subject to police investigation for alleged possession of child pornography on his personal computer. However, the criminal proceedings against him collapsed because his computer had been seized based on an expired search warrant. ${ }^{17}$ In response, the Oireachtas initiated removal proceedings against Judge Curtin, which he contested in the High Court and Supreme Court. While the removal process did not ultimately conclude because the judge first resigned, the Supreme Court ruling is nonetheless instructive for our purposes. Curtin's challenge was not based on the definition or scope of 'stated misbehaviour'; rather, he contested the constitutionality of the process adopted by the parliamentary standing orders for giving effect to the constitutional removal mechanism.

In essence, Curtin's main constitutional argument boiled down to the claim that it was a violation of constitutional rights to fair procedures for the Oireachtas to have adopted a process which would have seen a committee present an 'undigested' set of facts to the plenary membership of the Houses for consideration regarding an ultimate vote on removal. ${ }^{18}$ In other words, the standard set of natural-justice rights that would generally apply in advance of any such determination were argued not to have been upheld.

\footnotetext{
${ }^{15}$ Statement by An Taoiseach M. Martin TD, Dáil Eireann Debates, Thursday 17 November 2020 Vol. 1000 No. 7, 〈https://www.oireachtas.ie/en/debates/debate/dail/2020-11-17/2/\#spk_ 2), visited 16 June 2021.

${ }^{16}$ [2006] IESC 27.

${ }^{17} \mathrm{C}$. Coulter, 'Warrant was out of date when search of the residence took place', Irish Times, 24 April 2004, 〈https://www.irishtimes.com/news/warrant-was-out-of-date-when-search-of-the-residencetook-place-1.1309407?mode $=$ sample\&auth-failed $=1 \&$ pw-origin $=$ https $\% 3 \mathrm{~A} \% 2 \mathrm{~F} \% 2 \mathrm{Fwww}$.irishtimes. com\%2Fnews\%2Fwarrant-was-out-of-date-when-search-of-the-residence-took-place-1.1309407〉, visited 16 June 2021.

${ }^{18}$ [2006] IESC 27, at [118], per Murray CJ.
} 
Critically, the court accepted that the procedure adopted by the Oireachtas was, to say the least, far from ideal, from a natural-justice or procedural perspective. However, it nonetheless upheld the process based on a concern for the separation of powers. Arguing by analogy with previous cases concerning judicial review of executive powers, it concluded that where the Constitution vests specific powers in executive or legislature as one of the major organs of State, the courts can intervene only where 'clear disregard' of constitutional rights is established. ${ }^{19}$ In general, Irish Courts have preferred this doctrine of deference - allowing theoretically a limited residual scope for judicial intervention - providing very wide space for political decision while eschewing categorical principles of non-justiciability. ${ }^{20}$ Thus, while the full measure of procedural fairness that is normally required was implicitly lacking, the standard of 'clear' disregard, distinct from ordinary standards of constitutional violation, was not met. On this basis, it seems quite obvious that while the Oireachtas enjoys wide leeway with regard to the procedures adopted, for the same reasons it will almost certainly enjoy considerable, albeit not unlimited, autonomy in defining the substantive standard of 'stated misbehaviour' in specific cases - even where it not defined, legislatively or otherwise, in advance of any such proceedings.

In fact, this position accords with a longer trend of the judiciary understanding the political organs of state as enjoying a relative freedom in interpreting the constitution - notwithstanding the ultimate power of courts to make procedurally conclusive constitutional interpretations through judicial review of legislation and executive acts. Such relative political autonomy in constitutional matters was recognised, for example, in an early landmark case on constitutional rights, Ryan v Attorney General, where the Court stated:

the Oireachtas has to reconcile the exercise of personal rights with the claims of the common good and its decision on the reconciliation should prevail unless it was oppressive to all or some of the citizens or unless there is no reasonable proportion between the benefit which the legislation will confer on the citizens or a substantial body of them and the interference with the personal rights of the citizen. ${ }^{21}$

And despite a period of relative judicial activism from the 1970s, with the Supreme Court adopting a dynamic approach to interpretation and acting as an agent of social and policy change, this conceptualisation of constitutional rights as relatively indeterminate - and relatedly of the political organs as legitimately

${ }^{19}$ See e.g. T.D. v The Minister for Education [2001] IESC 101.

${ }^{20}$ See P. Daly, 'Judicial Review and 'Political Questions' in Ireland', 2 Judicial Studies Institute Journal (2008) p. 116. See also G. Hogan et al., 'An Anthology of Declarations of Unconstitutionality', 54 Irish Jurist (2015) p. 1.

${ }^{21}$ [1965] IR 294, at [312]. 
claiming a relative autonomy of interpretation - has endured. Indeed, it has been consolidated since the Court's retreat from activism from the 1980s onwards. On the one hand, the Irish Courts have arguably reverted to a kind of epistemic modesty in interpreting open-textured, abstract standards of constitutional law. ${ }^{22}$ And when it comes to reviewing legislative limitations on rights, they have acknowledged the relative indeterminacy of constitutional rights, stating that judges must not

impose their view of the correct or desirable balance in substitution for the view of the legislature ... but rather ... determine from an objective stance whether the balance contained in the impugned legislation is so contrary to reason and fairness as to constitute an unjust attack on some individual's constitutional rights. ${ }^{23}$

In summary, the constitutional framework in Ireland is characterised by judicial supremacy as a structural and procedural matter - connected with its accepted role as a cornerstone of constitutional democracy - but combined with judicial doctrines which recognise and even emphasise the legitimacy and necessity of significant spheres of autonomous political judgement.

Thus, what we have, in short, is a constitutional system in which judicial doctrines recognise a relatively wide latitude for political organs to engage in constitutional interpretation without judicial interference, but where - as illustrated in the impeachment episode - the political organs tend to resile from exercising that autonomy in practice.

\section{A 'Culture' of legalism in a political constitution}

Having outlined in the previous section how Irish constitutional doctrines recognise a relatively wide freedom of constitutional interpretation for political organs - in effect, a species of 'political constitutionalism' coexisting with procedural judicial supremacy - we now consider how this notional autonomy is frustrated in practice by a 'culture of legalism', drawing on several additional examples.

\section{A legalistic approach to politics}

Trying to 'determine the extent to which various sources of law internally constrain government actors ... is notoriously difficult'. ${ }^{24}$ This is particularly so when policymaking deliberations, and the legal concerns shaping them, rarely come to

\footnotetext{
${ }^{22}$ O. Doyle, The Constitution of Ireland: A Contextual Analysis (Hart Publishing 2018) at p. $166-167$.

${ }^{23}$ Tuohy v Courtney [1994] 3 IR 1, at [47].

${ }^{24}$ R. Pildes, 'Law and the President', 125 Harvard Law Review (2012) p. 1381 at p. 1395.
} 
the attention of most parliamentarians, let alone the public. But Irish politics has, in recent years, yielded several high-profile case studies in addition to the judicial impeachment example outlined above, which provide useful narrative accounts from elite political actors themselves about the effect of constitutional jurisprudence on policymaking. We will argue that the constraint imposed on political autonomy by perceived constitutional requirements forms a major part of this 'culture of legalism'.

\section{Property rights}

Between 2011 and 2020, the then Fine Gael-Labour coalition government and Fine Gael minority governments faced a deepening homelessness crisis. ${ }^{25}$ Both governments received considerable critique for their alleged lack of robust action. On at least a dozen different occasions, the government maintained that it faced very severe limitations on its scope for legislative action due to the Attorney General's advice on constitutional property rights.

The government asserted that several measures it hoped to adopt to tackle the growing housing crisis - including vacant site levies, land hoarding restrictions, the capping mortgage interest rates, eviction protections, and regulation of 'vulture funds' - were all stymied or diluted by the Attorney General's advice. ${ }^{26}$ After departing office, the then Minister for Housing, Alan Kelly, stated that it had been perceived constitutional constraints, rather than political or economic reasons, that blocked measures sincerely desired by the Fine-Gael/Labour government. ${ }^{27}$ Similarly, while backbencher parliamentarians during the 2016-2020 Fine-Gael minority government proposed several housing measures, the Government consistently asserted that such measures were either precluded by, or had to be diluted in order to protect, constitutional property rights. As a result, the Government asserted it could not support such measures even

\footnotetext{
${ }^{25} \mathrm{M}$. Nolan, 'Homelessness in Ireland is at crisis point, and the vitriol shown towards homeless people is just as shocking' New Statesman 5 February 2020 〈https://www.newstatesman.com/ politics/welfare/2020/02/homelessness-ireland-crisis-point-and-vitriol-shown-towards-homeless-people $\rangle$, visited 16 June 2021.

${ }^{26}$ D. Kenny and C. Casey, 'A One Person Supreme Court? The Attorney General, Constitutional Advice to Government, and the Case for Transparency', 42(1) Dublin University Law Journal (2019) p. 89.

${ }^{27} \mathrm{~K}$. Holland, 'Kelly says Constitution blocked attempts to tackle housing crisis', Irish Times, 31 March 2016, 〈https://www.irishtimes.com/news/social-affairs/kelly-says-constitution-blockedattempts-to-tackle-housing-crisis-1.2593962? mode $=$ sample\&auth-failed $=1 \& \mathrm{pw}$-origin $=$ https $\% 3 \mathrm{~A}$ $\% 2 \mathrm{~F} \% 2 \mathrm{Fwww}$.irishtimes.com $\% 2 \mathrm{Fnnews} \% 2 \mathrm{Fsocial}$-affairs\%2Fkelly-says-constitution-blocked-attemptsto-tackle-housing-crisis-1.2593962), visited 16 June 2021.
} 
if it was otherwise sympathetic to them, potentially giving itself political cover for opposing measures that may have been very popular during a housing crisis. ${ }^{28}$

For example, the Social and Affordable Housing Bill 2016, introduced by the opposition Labour Party in December 2016, proposed additional powers for local authorities to compulsorily acquire land for housing purposes at reduced rates, for strengthened rent controls, and for introducing a higher vacant site levy more quickly than the Government's proposal to increase it very incrementally. The Government opposed the Bill, citing constitutional concerns based on advice from the Attorney General that the proposal was a disproportionate interference with property rights. ${ }^{29}$ Then Minister for Housing Simon Coveney TD said that 'no one would rather introduce a levy earlier more than I would' but that he was not going to introduce something which he knew was, 'according to the advice of the Attorney General, not legally sound' as 'People will simply challenge it and we will lose' ${ }^{30}$ Similarly, the Government cited constitutional concerns to reject a 2017 opposition Bill ${ }^{31}$ proposing to create an independent mortgage arrears tribunal with powers to force banks and lending institutions to more equitably restructure a mortgage. The then Minister for Justice said that despite the 'positive intentions' behind the Bill, any

legislative interference with private property rights in this area seeking to achieve an objective of the common good still has to demonstrate clearly that it is a carefully balanced and strictly proportionate intervention which has taken full account of the respective rights and obligations of both parties. ${ }^{32}$

Similarly, opposition Bills aiming to prevent evictions, and specifically to restrict the grounds for termination of private leases, ${ }^{33}$ were opposed by Government despite constitutional justifications proffered by the deputies introducing them ${ }^{34}$ - based on the interference they allegedly represented in private property rights. As usual, the relevant advice of the Attorney General was not published. In respect of one of these Bills, the relevant Minister for State, Damien English

${ }^{28}$ D. Kenny and C. Casey, 'The Resilience of Executive Dominance in Westminster Systems: Ireland 2016-2019', Public Law (2021) p. 356.

${ }^{29}$ Dáil Éireann debate, Thursday 8 December 2016, Vol. 932 No. 2, 〈https://www.oireachtas.ie/ en/debates/debate/dail/2016-12-08/42/\#spk_197〉, visited 16 June 2021.

${ }^{30}$ Ibid.

${ }^{31}$ The Mortgage Arrears Resolution (Family Home) Bill 2017.

${ }^{32}$ Dáil Éireann debate, Wednesday 12 July 2017 Vol. 958 No. 1, 〈http://data.oireachtas.ie/ie/ oireachtas/debateRecord/dail/2017-07-12/debate/mul@/main.pdf), visited 16 June 2021.

${ }^{33}$ The Residential Tenancies (Prevention of Family Homelessness) Bill 2018 and Anti-Evictions Bill 2018.

${ }^{34}$ Dáil Éireann debate, Thursday 28 March 2019, Vol. 981 No. 2, 〈https://www.oireachtas.ie/en/ debates/debate/dail/2019-03-28/67/\#spk_403〉, visited 16 June 2021. 
TD, stated that any legislative action must respect the fact that landlords have constitutionally protected property rights that can be delimited only in a proportionate manner to achieve a legally justifiable social common good'. ${ }^{35}$

The Government's positions on many of these points were strongly contested by commentators who argued that they appeared to flow from a highly conservative and cautious interpretation of Supreme Court precedent. ${ }^{36}$ Hogan and Keyes, for example, argued that the Government's highly precautionary approach to housing issues relied heavily on legal advice that seemed at odds with a 'wide body of precedent that emphasises the power of the Oireachtas to abridge property rights where the common good so requires'. This, they argued, seemed to leave 'politicians and their advisors open to the charge that they are interpreting the Constitution and its case law as they would like it to be, rather than as it is ${ }^{37}$ More generally, the authors of a leading constitutional law treatise have recently remarked that, contrary to 'popular conception' held by many political actors, 'considerable latitude is given the Oireachtas to regulate and organise a modern economy. ${ }^{38}$

\section{Social/moral controversies}

This precautionary approach to constitutional limits has also been evident in debates on equality legislation, where constitutional freedoms of religions and association have often been used as a pretext for extensive derogations from equality law both for religious institutions and private clubs.

For example, prior to $2018^{39}$ constitutional religious freedom had been used to justify the commonplace practice of publicly funded schools requiring baptismal certificates as a criterion for enrolment. Deliberations on school admissions law in the mid-2010s provide a good example of the cowed approach of many political actors to policy issues implicating constitutional interpretation, even where they formally had extensive discretion over the issue. In 2014, the Oireachtas

${ }^{35}$ Dáil Éireann debate, Wednesday 12 December, 2018, Vol. 976 No. 5. 〈https://www. oireachtas.ie/en/debates/debate/dail/2018-12-12/35/\#spk_453), visited 16 June 2021.

${ }^{36} \mathrm{See}$ G. Hogan, 'Ireland: The Constitution of Ireland and EU Law: The Complex Constitutional Debates of a Small Country', in A. Albi and S. Bardutzky (eds.), National Constitutions in European and Global Governance: Democracy, Rights, the Rule of Law (Springer 2019) p. 1360.

${ }^{37}$ H. Hogan and F. Keyes, 'The Housing Crisis and the Constitution', 65(1) The Irish Jurist (2021) p. 87.

${ }^{38}$ The authors of the leading treatise on Irish constitutional law suggested in the preface to the most recent edition, 'considerable latitude is given the Oireachtas to regulate and organise a modern economy. The popular conception to the contrary is a pure myth': G. Hogan et al., Kelly: The Irish Constitution (Bloomsbury Professional 2018) p. xvii.

${ }^{39}$ The Education (Admission to Schools) Act 2018 removed the 'baptism barrier', which had allowed all religiously funded public schools to discriminate in favour of children of their own religious denomination. 
Education Committee debated draft legislation aimed at reforming school admissions criteria. While it considered submissions concerning denominational schools' exemption from the religious-discrimination prohibition, the Committee appeared to be dissuaded from making any firm recommendation on the issue by submissions claiming the derogation was constitutionally protected. ${ }^{40}$ The Chair of the Committee explained that while it is so obvious that giving priority to children because they have baptismal certificates or have been christened or brought up in a particular faith is discriminatory' and that there was 'no question but that the views expressed by committee members would be that this is not the ideal situation' the Committee 'could not really come up with a proposal to deal with that particular form of discrimination because of the Constitution'. Deputy Tuffy went on to say that their caution did not stem from moral/political division within the Committee, but from the fact they received different constitutional arguments from all sides of the debate, which made them feel like it was a 'very fraught issue' to act upon on as it seemed to lack a 'definitive answer' from the Courts. ${ }^{41}$

Political actors in this instance thus took a maximally precautionary approach to reform, not based on any moral/political reluctance, but seemingly out of a fear of legal challenge because the precise question before them had not been definitively adjudicated by the Courts - even though it seemed most likely, based on well-established doctrines, that restrictions on religious discrimination in Statefunded bodies would not be ruled to be an invidious or arbitrary limitation on religious freedom. The fear of legal risk and uncertainty alone seemed enough to paralyse political judgement, given that legislative action would not be forthcoming until 2018.

Around the same time, political debate emerged about the sensitive issue of allowing adopted people to access information concerning their original identity. In many respects, the pressing moral and political aspects of the debate swiftly became obscured by issues of legal risk, and particularly the constitutionality of granting automatic access to birth identity. While the relevant precedents suggested no such specific stipulation, the Attorney General issued unpublished advice to the Government, suggesting that the constitution would require provision for objections to adoption information access to be adjudicated on a

\footnotetext{
${ }^{40}$ Houses of the Oireachtas Joint Committee on Education and Social Protection, Report on the Draft General Scheme of an Education (Admissions to School) Bill 2013, (Dublin: Houses of the Oireachtas, 2013) p. 52, 〈http://data.oireachtas.ie/ie/oireachtas/committee/dail/31/joint_committee_ on_education_and_social_protection/reports/2014/2014-03-05_report-on-the-draft-general-schemeof-an-education-admission-to-schools-bill_en.pdf), visited 16 June 2021.

${ }^{41}$ Dáil Éireann debate - Friday 20 June 2014 Vol. 844 No. 4, 〈https://www.oireachtas.ie/en/ debates/debate/dail/2014-06-20/3/\#spk_17〉, visited 16 June 2021.
} 
case-by-case basis - a much more limited and cumbersome reform than most political actors clearly seemed to want.

During legislative debate in the Seanad (Senate), the sponsoring Minister, Katharine Zappone, said she would 'very much like to find a way to have a Bill which would allow unfettered access to information for those adults... which echoes the desires of the advocates who represent the people who have been adopted' but this was subject to it being 'acceptable to the Attorney General's understanding of the Constitution'. If this could be done, the Minister proclaimed, it would 'be fantastic' and she would 'be open to it'. ${ }^{42}$ Thus, reasoned political-moral judgement about rights ceded to highly opaque legal constraints emanating, critically, from the executive rather than judicial branch. It was later reported that instead of immediately acceding to the Attorney General's advice, Minister Zappone had first engaged in several rounds of correspondence defending the constitutionality of her proposals for automatic right to information, citing the contrary advice of constitutional lawyers the Minister had liaised with 'who offered $\ldots$ another way to interpret the Constitution' that emphasised the Oireachtas' extensive discretion over sensitive moral/social issues. ${ }^{43}$ However, the Attorney General declined to change his view and the Minister did not pursue her preferred policy as initially proposed but reached a compromise which diluted it substantially in such a way that complied with the Attorney General's position.

\section{Remote sittings of parliament}

Following the onset of the Covid-19 pandemic and the curtailment of parliamentary business in line with public health advice, several deputies of Dáil Eireann called for the Houses and committees to conduct business remotely. ${ }^{44}$

\footnotetext{
${ }^{42}$ Seanad Eireann Debate - Wednesday, 12 June 2019, Vol. 266 No. 2, 〈https://www.oireachtas. ie/en/debates/debate/seanad/2019-06-12/21/\#spk_191), visited 16 June 2021.

${ }^{43}$ J. Bray, 'Way Cleared for Law Releasing Birth Data to Adopted People', Irish Times, 5 November 2019, 〈https://www.irishtimes.com/news/politics/way-cleared-for-law-releasingbirth-data-to-adopted-people-1.4072396? mode $=$ sample\&auth-failed $=1 \& \mathrm{pw}$-origin $=\mathrm{https} \% 3 \mathrm{~A} \% 2 \mathrm{~F}$ \%2Fwww.irishtimes.com\%2Fnews\%2Fpolitics\%2Fway-cleared-for-law-releasing-birth-data-to-adoptedpeople-1.4072396), visited 16 June 2021. Note that the General Scheme for a Birth Information and Tracing Bill, allowing access to birth certificates and early-life information, was published by the Minister for Children, Equality, Disability and Youth on 11 May 2021. See press release, 'Minister O'Gorman publishes proposed Birth Information and Tracing Legislation', Department of Children, Equality, Disability and Youth, 11 May 2021. Regarding possible constitutional limits on such measures, see, however, South Western Area Health Board v Information Commissioner [2005] IEHC 177.

${ }^{44}$ 'Virtual gatherings of Dáil and Seanad not permitted', RTE News, 20 April 2020, 〈https:// www.rte.ie/news/politics/2020/0420/1132695-virtual-gatherings-of-dail-and-seanad-not-permitted/ $\rangle$, visited 16 June 2021.
} 
However, the Dáil Business Committee sought and received advice from the Office of Parliamentary Counsel, via an external senior counsel, who advised that remote sittings would not be constitutional. While the full advice has not been published, it has been revealed that it argues that a virtual sitting would not conform with the requirements of Article 15 of the Irish Constitution as 'members would not be sitting publicly in the same place, and they would not be within the precincts of either House so as to benefit from immunities in respect of utterances'. ${ }^{45}$ On behalf of the Business Committee the Ceann Combairle (chair) confirmed that the legal opinion also advised that public sittings of the Houses of the Oireachtas must be conducted in an identified 'place'. The opinion stated:

The notion of 'place' as envisaged by the Constitution requires an assembly of a group of people gathered together in one place for a common purpose... the members of a 'virtual Parliament' would not be gathered together or sitting publicly in the same place.

This advice was widely considered to have been based on a highly formalist, even originalist, reading of constitutional text. ${ }^{46}$ Despite this having a serious impact on the Oireachtas' ability to discharge its core functions, political actors chose to bind themselves to an opinion of one senior lawyer that was regarded by many other legal commentators as being overly cautious and as needlessly inimical to the functioning of the legislature. As remote sittings were ruled out, the Business Committee eventually opted to decamp from Leinster House to a larger private commercial venue, where the entire complement of deputies could be sat for limited periods, all at considerable expense. ${ }^{47}$ Most of the legislature's critical Committee work ground to a halt for several months. A special Covid-19 Committee was established to continue to meet in Leinster House in a socially distant manner. But this committee had an unusually large brief to manage essentially every socio-economic facet of Covid-19 - with a limited meeting time

\footnotetext{
${ }^{45}$ Ibid.

${ }^{46} \mathrm{C}$. Casey et al., 'Remote Sittings of the Houses of the Oireachtas: A constitutional solution to a potential democratic deficit', Constitution Project, 7 April 2020, 〈http://constitutionproject.ie/?p= $770\rangle$, visited 16 June 2021; D. Kenny, 'Remote sittings for Ireland's parliament: questionable constitutional objections', Constitution Project, 23 May 2020, 〈https://constitution-unit.com/tag/davidkenny/>, visited 16 June 2021; S. Ó Conail, 'Remote Dáil Sitting - A Textual Analysis', Constitution Project, 20 April 2020, 〈http://constitutionproject.ie/?p=774〉, visited 16 June 2021.

${ }^{47}$ 'Government use of Convention Centre cost almost $€ 500 \mathrm{k}$ in one month', Irish Examiner, 11 September 2020, 〈https://www.irishexaminer.com/news/arid-40046930.html , visited 16 June
} 2021. 
of once a week for several hours. ${ }^{48}$ The regular committees of the Oireachtas were effectively not working at all from April to October 2020, making them unable to discharge their task of scrutinising the work of government departments and public bodies under their remit. Most seriously, the absence of Dáil committees clearly hobbled its ability to discharge its function of holding the executive to account during a period where it was delegated unprecedented authority.

The willingness of the Oireachtas to shut itself down voluntarily and effectively abdicate its own powers to conduct scrutiny work and hold the Government to account, due solely to the contested legal advice of one senior counsel, is again testament to the legalistic and precautionary approach adopted by political actors in exercising political judgement regarding constitutionally sensitive matters. Again, this precautionary - even cowed - approach, obtains notwithstanding the wide latitude to political actors afforded by judicial doctrines themselves.

\section{Analysis}

From these case studies it is clear that Irish political culture is heavily legalised. This legalistic approach to political discretion and judgement implicating constitutional law seems to comprise the following characteristics:

- an outsized concern about legal uncertainty and the risk of legal challenges being brought;

- a notable reluctance to advance policy where a risk of legal challenge exists, even where ample precedents support the measure and the ultimate likelihood of judicial invalidation is modest;

— an emphasis on minimising any risks of challenge by requiring proof of the strict necessity of State intervention;

- an emphasis on designing measures touching on individual constitutional rights with very cautious and painstaking balancing and calibration so they can be viewed as strictly tailored;

- a strong deference to legal advice, to the extent it is viewed as effectively binding;

- a tendency to conceptualise the Constitution as brake or barrier on state action, rather than as a positive source of political empowerment.

\section{Extensive judicial deference}

What is perhaps surprising is that this highly cautious approach to many political questions exists alongside an extensive constitutional jurisprudence, alluded to in

\footnotetext{
${ }^{48}$ The terms of reference for the Committee are available at 〈http://data.oireachtas.ie/ie/ oireachtas/parliamentaryBusiness/orderPaper/dail/2020/2020-05-06_dail-supplementary-order-paperwed_en.pdf $\rangle$, visited 16 June 2021.
} 
the first section above, which gives significant space for the political branches to exercise their powers free from judicial second-guessing. Notwithstanding its very robust formal powers, the Irish Supreme Court has over time assumed a 'comparatively modest role in interpreting and enforcing the Constitution'. ${ }^{49}$ For example, as touched upon above, the Courts have emphatically said that it is primarily the role of the Oireachtas to regulate the exercise of individual constitutional rights by reference to the exigencies of the common good, and to reconcile conflicting constitutional rights. These legislative judgements are afforded a strong presumption of constitutionality, of which the burden of overturning is placed squarely on the plaintiff. This presumption has 'particular force in cases where the legislature is concerned with the implementation of public policy in respect of sensitive matters of social or moral policy..$^{50}$

The Courts have insisted, in case after case, that the Oireachtas has ample authority and leeway when enacting laws to secure the common good, even if individual rights or interests must give way.

If anything, the relatively modest approach adopted by courts themselves has become pronounced over time, ever since the seminal statement in Ryan $\mathrm{v}$ Attorney General considered above. This seems to apply in particular to social and economic questions. Take Shirley v O'Gorman, ${ }^{51}$ for example, where the High Court rejected the contention that individual property rights could only be altered or regulated by the State pursuant to Article 43 in situations where doing so was an 'absolute necessity' for the common good. In a passage whose tenor pithily conveys the Court's general attitude to the regulation of sensitive socio-economic issues, Peart J. held that this contention would be unduly burdensome on the political branches and that:

$[\mathrm{O}] \mathrm{f}$ course the Courts enjoy an ultimate supervisory role in ensuring that legislation passed by the Oireachtas is constitutional, but the Courts should be slow to in any way to substitute its own view of what may or may not be required in order to reconcile the exercise of property rights with the exigencies of the common good. Until some point of absolute extremity is reached where legislation is patently and manifestly not in pursuit of any possible common good exigency, the Court should abstain from interfering with the role of the legislature in deciding what measures are needed.

The Courts thus seem conscious that the Constitution speaks in majestic generalities - using vague terms like liberty, dignity, freedom, social justice, and the

\footnotetext{
${ }^{49}$ See E. Daly, 'Reappraising judicial supremacy in the Irish constitutional tradition', in T. Hickey et al. (eds.), Judges, Politics and the Irish Constitution (Manchester University Press 2017) p. 29.

${ }^{50}$ Fleming v Ireland [2013] 2 IR 417 at 441.

${ }^{51}$ [2006] IEHC 27.
} 
common good - such that what it stipulates, in specific controversies, is relatively indeterminate from a juristic point of view. ${ }^{52}$ Even the Court's adoption of the proportionality test - an ostensibly more rigorous test than reasonableness or rationality review - has, notes Kenny, been characterised by very extensive deference to the political branches. ${ }^{53}$

Deference also extends to the Oireachtas' regulation of its own affairs. The Courts have made it clear that, by and large, parliamentary standing orders and procedures are not justiciable. In O'Malley v An Ceann Combairle, ${ }^{54}$ the respondent Chair of the lower house had made changes to the applicant's parliamentary question without his knowledge. Despite the fact that the respondent's actions appeared to be in clear violation of the Dáil's standing orders, the Supreme Court concluded:

How questions should be framed for answer by Ministers of the Government is so much a matter concerning the internal working of Dáil Éireann that it would seem to be inappropriate for the Court to intervene except in some very extreme circumstance which it is impossible to envisage at the moment.

Similarly, in Haughey v Moriarty, ${ }^{55}$ the Supreme Court refused to hear evidence relating to an argument advanced by one of the parties that the Seanad had, not in this instance, been convened properly. Geoghegan J noted that '.. . these matters were not justiciable in the courts on the grounds of the constitutional separation of powers. The Dáil and the Seanad regulate and enforce their own procedures'. ${ }^{56}$ Deference is certainly not unlimited, especially when individual constitutional rights like a right to fair procedures and one's good name are involved, ${ }^{57}$ but judicial doctrine clearly creates very extensive zones of autonomy for explicitly political judgement about how best to structure the work of the legislature.

This wide latitude given to the political judgements of the Oireachtas exists in the context of a polity with a strong tendency toward executive dominance, with power and policymaking concentrated in the Government. This dominance is

${ }^{52}$ Daly, supra n. 49 , at p. 37-39.

${ }^{53} \mathrm{D}$. Kenny, 'Proportionality and the Inevitability of the Local: A Comparative Localist Analysis of Canada and Ireland', 66 American Journal of Comparative Law (2018) p. 563-564.

${ }^{54}$ [1997] 1 IR 427.

${ }^{55}$ [1999] 3 IR 1.

${ }^{56}$ Ibid.

${ }^{57}$ Maguire v Ardagh [2002] 1 IR 385; Re Haughey [1971] IR 217; Callely v Moylan [2014] 4 IR 112; Kerins v McGuinness [2019] 2 ILRM 301. For a good overview of the Court's attempts to balance safeguarding the autonomy of parliamentary affairs with fair procedures see T. Hickey, 'Justiciability and proceedings in the Oireachtas: the case of Angela Kerins', 4 Public Law (2020) p. 610. The scope and limits of deference were recently the subject of judicial discussion in Bacik v An Taoiseach [2020] IEHC 313. 
underpinned both by its tight control over the legislative process, facilitated by very strong party discipline, and the fact the Government sits atop a potent bureaucratic apparatus vested by the Oireachtas with extensively statutory authority to regulate swathes of socio-economic life. Given the very close relationship between the political branches - some even contend Ireland's separation of powers is essentially bipartite - functionally speaking the judiciary offers very wide latitude to the Government of the day to implement its policymaking agenda and to exercise political judgement to act for the common good. ${ }^{58}$

\section{Solving the puzzle: lawyers and legalism}

It is challenging to offer any single definitive explanation as to how these contrasting attributes of constitutionalism - the officially wide latitude of constitutional interpretation for political organs, along with the legalistic culture of political life itself - can coexist.

While, procedurally speaking, the Supreme Court enjoys the last word on the constitutionality of legislative and executive acts, ${ }^{59}$ that does not entirely explain why - after the Courts have long recognised a relatively wide political autonomy over constitutional matters - the political organs would continuously adopt such a precautionary and legalistic approach. The question arises, then, why the constitutional authority the political branches enjoy, to exercise political discretion and judgement for the common good, has in practice been eschewed in favour of risk minimisation - an approach whose overall effect is to favour inertia and policy minimalism.

While there can be no single definitive explanation for this 'culture of legalism', we argue that it can in large part be attributed to a wider social understanding of constitutional law as a narrow expert craft, as a corpus of professional knowledge that is politically and morally neutral. This understanding prevails, in different extents, amongst citizens, politicians, lawyers, judges, civil servants, academics - and its effect is to narrow the remit and autonomy of political and moral debate of the sort that might otherwise features in legislative process.

Conor O'Mahony, a prominent Irish public law scholar, encapsulated this view when he argued that politicians are ill-suited to engage with constitutional interpretation, on the basis that it is

highly specialized and technical task, and the judges charged with it are selected on the basis of years of training and experience and having demonstrated their knowledge and competence on many occasions. As against this, many politicians will have no formal training in law, much less constitutional law.

${ }^{58}$ Doyle, supra n. 22, p. 46.

${ }^{59}$ Daly, supra n. 49. 
If one accepts the characterisation of constitutional interpretation as a practice requiring special 'training', 'experience', 'knowledge' and 'competence' - and it is apparent most elite political actors do - then one may conclude without undue difficulty that in 'the same way that the courts are not as well placed to make decisions on questions of national policy as the political organs are, the political organs are not as well placed to decide what the Constitution requires as the courts'. ${ }^{60}$

Regarding this apparent 'culture of legalism', we follow Pierre Bourdieu's understanding of 'the law' as a semi-autonomous social 'field' generating its own forms of symbolic power - a power that resides primarily in the capacity of the actors within that field to make socially authoritative claims about what the law is, using the requisite linguistic and discursive techniques. ${ }^{61}$ Symbolic power, in this sense, lies partly in the capacity of the relevant participants in this field, those possessing the requisite professional competences, to have such capacities naturalised and universalised - in other words, to have these accepted as having a natural value and legitimacy considered apart from the social status or distinction they may confer upon the competent participants. In Ireland, the legal 'field' is relatively insular and socially homogenous, characterised, as Doyle argues, by a shared ideological perspective, with a sort of common sense about what constitutional law requires being 'communicated seamlessly' between the relatively close-knit participants in this professional-epistemic community. ${ }^{62}$

Where constitutional law is understood in wider society as a highly specialist and technocratic activity, the juridificaion of political debates with constitutional implications expresses the social power, exercised symbolically, of those who determine the meaning of the law, and succeed in having this rendered and accepted as authoritative beyond the field of law itself. Correspondingly, this symbolic power exercised by legal actors diminishes the authority and autonomy of politics, and particularly the epistemic authority of political actors, to speak authoritatively on political matters that implicate constitutional issues. Notwithstanding judicial doctrines which provide extensive discretion to the Oireachtas and make allowance for political/moral criteria, political actors nonetheless regard constitutional interpretation in more or less exclusively juristic terms. Political actors thus continue to regard constitutional standards, regardless of their moral-political character, as a 'set of supra-political constraints on

${ }^{60}$ C. O'Mahony, 'Societal Change and Constitutional Interpretation', 1 Irish Journal of Legal Studies (2010) p. 71 at p. 96.

${ }^{61} \mathrm{P}$. Bourdieau, 'The force of law: Towards a sociology of the juridical field', 38 Hastings Law Journal (1987) p. 818.

${ }^{62}$ Doyle, supra n. 22, p. 154. See also O. Doyle, 'Conventional Constitutional Law', 38 Dublin University Law Journal (2015) p. 311. 
legislative and policy choices that is indecipherable to lay reasoning' ${ }^{63}$ (notably, unlike in other states, Irish politicians tend not to have a unified disciplinary or educational background, typically being drawn from an amorphous range of professional and academic backgrounds.)

One consequence of political actors' reticence in this regard is their implicit ceding of a large degree of influence over policymaking to lawyers, actors who are regarded as having suitable expertise to engage in constitutional interpretation. In particular, the eco-system of lawyers who provide legal advice to the political branches - the Attorney General's office, the Office of Parliamentary Legal Counsel, and the small circle of senior barristers externally briefed to provide opinions for these actors ${ }^{64}$ - appear to exercise a significant influence over how the political branches engage with constitutional interpretation, including accessible concepts which encompass non-specialist moral and political principles within them. Carolan notes that the work of this eco-system is perhaps the 'most significant constraint in the Irish system on the content of public policy ${ }^{35}$ given that judicial review only touches a sliver of legislative activity. Casey and Kenny similarly argue that its work can be regarded as a form of 'shadow constitutional review' where confidential legal advice on the constitutionality of proposed legislation functionally acts as a binding ex-ante veto over policy. ${ }^{66}$

All in all this amounts, as we have argued, to a significant degree of symbolic power and epistemic authority for the law - not understood formally or institutionally in the sense of the powers held by the judicial branch, but holistically, as a social 'field' or ecosystem. Like other discursive and social practices, constitutional lawyering confers a 'kind of social power' that stems not from 'mere knowledge of the relevant subject, but rather, from a particular kind of relation between speaker and audience. ${ }^{67}$ In this case, the social power of elite lawyers stems as we have argued, from being perceived and accepted by an influential audience of political actors as having the 'requisite competences and techniques' ${ }^{68}$ to engage in the specialised task of constitutional interpretation. Irish political elites regard the lawyers who advise them as enjoying an apolitical and disinterested 'cognitive authority' over constitutional interpretation that is inaccessible to lay persons

${ }^{63}$ E. Daly, 'Transparency as a Justification for Legislative Supremacy', 23 Critical Review of International Social and Political Philosophy (2020) p. 807 at p. 826.

${ }^{64} \mathrm{E}$. Carolan, 'The Constitution, politics and public policy', in D. Farrell and N. Hardiman (eds.), Oxford Handbook of Irish Politics (Oxford University Press 2020).

${ }^{65}$ Ibid.

${ }^{66}$ D. Kenny and C. Casey, 'Shadow Constitutional Review: The Dark Side of Pre-Enactment Review in Ireland and Japan', 18 International Journal of Constitutional Law (2020) p. 51.

${ }^{67}$ Daly, supra n. 63.

${ }^{68} \mathrm{Ibid}$. 
who lack the requisite training and experience; ensuring a certain esotericisation of the political-moral reasoning comprised in constitutional law. ${ }^{69}$

This is not to say most lawyers involved in this eco-system are even aware of the significant influence they exercise over policymaking. If asked, they would likely say they have no desire to influence politics and are dedicated solely to carrying out their professional duties: providing objective legal advice to the best of their ability while attempting to assist and guide their client in respect of their goals, subject always to the strict ethics of the profession. In one sense this response would undoubtedly be accurate. Irish lawyers are fiercely proud of their long tradition of institutional independence from the State, and there is no evidence to suggest that they give advice to political actors in a partisan political matter - for example giving favourable advice to advance explicitly ideological aims - as has been alleged of lawyers in some legal systems. Nor is there any obvious evidence that their influence on policymaking is somehow 'derivative in some sense of extraneous desiderata' like social and economic interests, ${ }^{70}$ at least not in a conscious or direct sense. Rather, the field of law is structured and reproduced based on the transmission and naturalisation of the linguistic and discursive capacities that constitute a certain 'feel of the game', a capacity to navigate and speak authoritatively in a peculiar epistemic and symbolic universe that enjoys relative autonomy from other social fields.

Regardless of intent, this symbolic and social power of lawyers has a political impact in shaping the approach of political actors to policy and legislation. It generates epistemic constraints that tie political actors to the understandings and habitus of a particular professional community, with its implicit set of understandings and dispositions toward the relationship between politics and law. Capturing the attitudes of this professional-epistemic community and its set of understandings and dispositions concerning the relationship between constitutional law and politics is difficult, partly because of the confidentiality of legal advice. But inferences can be made from the public presentation of advice and its deployment in political discourse, as our case studies demonstrated. Assuming that these representations of constitutional advice are accurate, this professional culture parallels the political orientation towards constitutional constraint considered above, with the following characteristics in particular:

- a heavy focus on risk minimisation;

- careful attention to whether policies, particularly those with ambitious scope, might engage the interests of constitutional rights-holders with the incentive and means to take litigation; ${ }^{71}$

${ }^{69}$ Ibid.

${ }^{70} \mathrm{Ibid}$.

${ }^{71}$ Carolan, supra n. 64. 
- an awareness of the risk that even an ultimately successful defence of a challenged policy may 'lead to significant delays and costs on the part of the State'; $; 2$

- an assumption that the best way to minimise risk is to practise cautious 'political risk-avoidance in the design or introduction of policy measures', whether by diluting, or excessively proceduralising preferred policies, or requiring elevated burdens of proof as to their necessity and efficacy. ${ }^{73}$

What we can infer from this pattern, in particular, is that a peculiar premium is placed on risk aversion in the sense of minimising the risk of constitutional invalidation or even of legal challenge altogether, in a manner that outweighs any possible premium for the common good that the relevant legislation may represent. ${ }^{74}$

As the political branches have long relied on this professional-epistemic community both to decode and anticipate the rulings of the superior courts for their import on policymaking, it is inevitable that their attitudes as legal practitioners would seep into the political process and political discourse. Because of the deference lawyers are afforded, it weds the political branches to an implicitly anti-reformist, small-c conservative, orientation toward the relationship between politics and constitutional law, which bleeds into political discourse and how actors view the Constitution only as a source of constraint. ${ }^{75}$ This, again, reflects Bourdieu's observation that 'when esoteric discourses are diffused outside the restricted field', they 'undergo a kind of automatic universalization, ceasing to be merely the utterances of dominant agents within specific fields and becoming statements valid for all dominating or dominated individuals', in this case for political actors who feel epistemically constrained from engaging in constitutional interpretation on their own terms. ${ }^{76}$

To paraphrase Appleby and Olijnyk, this kind of 'constitutionally conservative' approach to policy development risks 'constitutional - and potentially social - stagnation'. ${ }^{77}$ This is not necessarily a critique, as some may welcome the cautious and risk-minimising approach elite lawyers take toward these issues, and regard 'incrementalism' as a suitable and less pejorative appellation than 'stagnation' to describe its social impact. But whatever its normative merits, their

\footnotetext{
${ }^{72}$ Ibid.

${ }^{73}$ Ibid.

${ }^{74}$ It is similar to what Adrian Vermeule dubs 'precautionary constitutionalism', which takes an approach to political and legal risk oriented to 'warding off the worst case' whether it be official abuse of power or overstepping legal bounds: A. Vermeule, The Constitution of Risk (Cambridge University Press 2014) p. 13.

${ }^{75}$ Daly, supra n. 63.

${ }^{76}$ P. Bordieu, Language and Symbolic Power (Harvard University Press 1999) p. 4.

${ }^{77}$ G. Appleby and A. Olijnyk, 'Executive Policy Development and Constitutional Norms: Practice and Perceptions', 18 International Journal of Constitutional Law (2021) p. 1136 at p. 1143.
} 
influence cannot be regarded as apolitical - given the cautious legalistic approaches to political judgement adopted by this group, and by implication those they advise, they clearly have an important impact on how State power is used, or not used. ${ }^{78}$

\section{Executive sometimes takes advantage of legalistic discourse}

One challenge to our argument might be that political actors are not truly hemmed in by epistemic constraints, and that what may look like a cautious, legalistic, approach to political discourse is in fact often a tactical rationalisation of political reticence to take a particular policy action. In other words, political actors do not see their space for political judgement as always bound by a cautious legalism, but tactically convey the impression to side-step pressure to take political action it simply does not want to take. It may also be argued that what might look like epistemic constraint and deference to expertise is in fact misleading strategic use of confidential legal advice which may well be equivocal but presented as unequivocal to shore up its position. We agree that it is plausible that political actors might tactically adopt a legalistic approach to give cover to their ideological goals and defuse political critique, given both the highly confidential nature of advice and, in some instances, the very stark gap between jurisprudence and the thrust of advice. ${ }^{79}$

Regardless, this possibility is consistent with our 'culture of legalism' thesis. First, there is no evidence that political actors feel confident engaging in constitutional interpretation themselves or have competence to depart from legal advice - regardless of whether legal constraints are perceived cynically or in earnest. Second, it is worth stressing that in order for such a rationalisation to even be regarded as a legitimate political move, any such exploitation of legal advice must have a receptive audience of political actors willing to defer to constitutional expertise in the first place.

\section{Political Constitutionalism Under a CUlture of Legalism}

\section{Relevance to legal and political constitutionalism}

So far, we have argued that whereas Irish constitutional doctrines recognise a relative autonomy for political actors in interpreting constitutional standards, this autonomy is nonetheless disavowed in practice under a 'culture of legalism' within political life itself. In this final section, we aim to draw out the implication of this idea for the concept of political constitutionalism itself.

\footnotetext{
${ }^{78}$ See Hogan and Keyes, supra n. 37.

${ }^{79}$ Kenny and Casey, supra n. 26.
} 
In particular, we argue that the autonomy of political judgement that political constitutionalism implicitly aims to preserve can be understood in 'cultural' - or at least epistemic - terms, rather than merely in terms of the formal allocation of institutional powers. Political constitutionalism may, in short, be undermined by the symbolic power of the law as felt in the sphere of politics itself. Analytically, the main implication our of argument is that considerations of formal allocations of institutional power to judges, and even how it is exercised in adjudication and interpretation, are inadequate by themselves to explain how political actors approach constitutional law and its effects on policymaking and political discourse. Rather, a robust account must also engage with the epistemic orientations of political actors toward constitutional law and interpretation - particularly questions such as whether they conceive of it as a legalistic subject matter demanding a highly technocratic skillset to navigate. A convincing account must also consider how such beliefs might constrain the autonomy of political judgement as well as the formal allocation and exercise of powers, such as interpretive supremacy, the ability to invalidate statutes or declare them incompatible with constitutional rules. Simply put, a robust account of why political actors approach political discourse in the manner they do cannot ignore social perceptions of constitutional law in a given political community; instead, it must examine 'how actors understand the legal and political practices that they participate in'. ${ }^{80}$

We suggest that this has some novel implications for participants in the, arguably now exhausted, battle over the merits of political or legal constitutionalism. Mac Amhlaigh offers a useful recapitulation this long and winding debate when he points out that the most 'popular front' of the battle between political and legal constitutionalism has been with 'regard to the question of whether courts or legislatures should have ultimate decision-making authority on the identification, interpretation and application of the fundamental values, usually expressed as fundamental rights, of a particular legal order or constitutional settlement' ${ }^{81}$ In other words, who enjoys constitutional authority to make these kind of determinations for the other branches?

While no canonical definition exists, it is fair to say that those on the political constitutionalism side of the debate are typically concerned by the juridification of political life, ultimately because at a deep philosophical level, they place a premium on the autonomy - or at least the relative autonomy - of political judgement. Our case study will be of interest to political constitutionalists, as it suggests that juridifictaion does not necessarily stem, at least predominantly,

\footnotetext{
${ }^{80} \mathrm{~A}$. Latham-Gambi, 'Political Constitutionalism and Legal Constitutionalism - an Imaginary Opposition?', 40 Oxford Journal of Legal Studies (2020) p. 737 at p. 762.

${ }^{81}$ C. Mac Amhlaigh, 'Putting Political Constitutionalism in its Place', 16 International Journal of Constitutional Law (2015) p. 175 at p. 176.
} 
from the formal constitutional powers of courts and questions of who has formal constitutional authority to definitively interpret the Constitution for the other branches. Rather, it may stem from the sociological orientation of the political and legal 'fields', and particularly, the symbolic power of lawyers and law as experienced and internalised in the practice of politics. Latham-Gambi has recently argued that political and legal constitutionalism may be understood in terms of a 'cleavage of social imaginary', through 'contrasting ways of imagining the political world'. ${ }^{82}$ We seek to build on such analysis by conceptualising the 'culture of legalism' as a type of symbolic power wielded in the field of politics. Crucially, this culture of legalism, and the sort of epistemic imperialism it effects, does not necessarily depend on the existence - or at least the enthusiastic exercise of formal powers - of judicial review. This suggests that any attempts to cultivate an approach to constitutional politics characterised by 'Thayerian deference, ${ }^{83}$ 'departmentalism', 84 'popular constitutionalism' ${ }^{85}$ or the 'New Commonwealth Model' $^{86}$ third way between legislative and judicial supremacy, seem highly implausible absent the requisite sense of epistemic authority amongst political actors.

This argument also seems to have critical bite in systems aside from Ireland's. Speaking in respect of the UK, Canada and New Zealand, Latham-Gambi has recently given an account of why attempts to combine, via political-rights review, 'legal and moral/political conceptions of rights, and ... judicial and legislative rights reasoning' have consistently failed. He starkly outlines this failure as follows:

Nowhere do we see executives or legislatures conducting the kind of critical engagement with judicial decisions that would be necessary to provide a combination of 'legal' and 'political' forms of reasoning capable of combining the strengths, while avoiding the weaknesses, of both. Instead, political rights review has operated with 'a highly juridical orientation to constitutionalism', treating the assessment of legislation against constitutional standards as a prediction of what would likely be decided if the provisions were to be tested in court. ${ }^{87}$

${ }^{82}$ Latham-Gambi, supra n. 80, at p. 762.

${ }^{83} \mathrm{E}$. Garrett and A. Vermeule, 'Institutional Design of a Thayerian Congress', 50 Duke Law Journal (2000) p. 1277.

${ }^{84}$ R.H. Fallon, 'Judicial Supremacy, Departmentalism, and the Rule of Law in a Populist Age', 96 Texas Law Review (2018) p. 487.

${ }^{85}$ See R. Post and R. Siegel, 'Popular Constitutionalism, Departmentalism, and Judicial Supremacy', 92 California Law Review (2004) p. 1027; L.D. Kramer, The People Themselves: Popular Constitutionalism and Judicial Review (Oxford University Press 2004).

${ }^{86} \mathrm{~S}$. Gardbaum, The New Commonwealth Model of Constitutionalism: Theory and Practice (Cambridge University Press 2013).

${ }^{87}$ Latham-Gambi, supra n. 80, at p. 759. 
For Latham-Gambi, the reason for this failure is that each system tried to 'craft roles' for institutions and constitutional actors, through formal legal means, that departed 'from constitutional imaginary understandings' of the appropriate roles of these institutions held by the very same political actors staffing them. ${ }^{88}$ In each system, political officials simply did not see it as a legitimate aspect of their constitutional role to enjoy institutional competence to engage in questions of constitutional or legal interpretation. ${ }^{89}$ It is far beyond the scope of this article to speculate how cultivation of the requisite sense of epistemic authority to speak to constitutional questions by political actors could come about, but our arguments suggest it would likely involve the enormously ambitious undertaking of capturing the imagination of officials and citizens, and provide a new way of understanding the nature of a constitution and the relationship between politics and law. ${ }^{90}$

Our arguments also have relevance for proponents of legal constitutionalism, as many will be equally unsatisfied with a highly legalistic approach to political discourse. They may want a state capable of pursuing ambitious socio-economic policy goals for the common good and able to exercise political discretion up to the fullest degree of its constitutional authority, and that it be policed on the margins by a watchful and independent judiciary who retains the final word on 'what the law is'. But they certainly may not want political actors to regard constitutional law as an esoteric intellectual endeavour whose navigation implicitly warrants extensive reliance on, and deference to, lawyers whose advice may turn on a myopic fear of legal challenge and judicial invalidation, given this might lead to a serious ossification of policymaking and cow robust political action for the common good. If this is the case, then legal constitutionalists would also do well to focus more attention to how a system can ensure that judges can retain the last word on constitutional interpretation, while also ensuring that the enterprise does not become regarded as an abstruse technical skill that political actors ought to approach with maximal caution and deference to lawyers.

\section{The autonomy of political judgement}

Our analysis invites reappraisal of the ultimate value or grounds of political constitutionalism. It has been justified by its most noteworthy defenders on several normative grounds, including the liberal-democratic grounds of formal

\footnotetext{
${ }^{88}$ Ibid., at p. 760.

${ }^{89}$ J.L. Hiebert, 'Parliamentary Bills of Rights: An Alternative Model?', 69 Modern Law Review (2006) p. 7 at p. 28.

${ }^{90}$ Latham-Gambi, supra n. 80, at p. 739.
} 
procedural equality (Waldron) ${ }^{91}$ and the republican grounds of non-domination in the political process (Bellamy). ${ }^{92}$ While sympathetic to such perspectives, we argue that, with the Irish example in mind, political constitutionalism may also be appraised in terms of a more general value: the autonomy of political judgement. Political freedom, in its procedural and electoral dimension, may well require the formal equality, the 'one person, one vote' premise that political constitutionalists like Waldron and Bellamy emphasise so heavily.

However, along with and in addition to this procedural element of democratic political freedom, a separate and rich vein of intellectual history and political thought emphasises the importance of maintaining a sphere in which political freedom can take effect through political speech and action - a domain in which specifically political forms of judgement and action may occur, and in which citizenship, intimately connected with the life of political action, can acquire shape and meaning. This political domain can be understood, in the Aristotelian sense, as a public sphere in which man's political telos can be realised, or in the Arendtian sense, as a 'space of appearances' in which citizens realise themselves in the virtuosity of act and speech. ${ }^{93}$

This importance of maintaining a wide domain for autonomous political judgement can also understood in light of the Machiavellian tradition of 'republican existentialism' which sees fortuna - or roughly, contingency - as the very condition or circumstance of politics, and of citizenship and political freedom being realised in the improvised actions that navigate it. As Machiavelli himself memorably put it, political authorities must grapple with the reality 'things arise and accidents come about that the heavens have not altogether wished to be provided against'. ${ }^{94}$ This Machiavellian concern insists on the preservation of a sphere in which political judgement can act in a way that responds to the novel and unforeseen, that is unprincipled, unnormativised in short, unlegislated for. Indeed Richard Bourke, in discussing the nature of political judgement, describes the peculiarly important political capacity of 'practical imagination, inventiveness or creativity, of coming up with new possibilities, or seeing new possibilities. ${ }^{95}$

${ }^{91}$ J. Waldron, 'The Core of the Case against Judicial Review', 115 Yale Law Journal (2006) p. 1346.

${ }^{92} \mathrm{R}$. Bellamy, Political Constitutionalism: A Republican Defence of the Constitutionality of Democracy (Cambridge University Press 2007).

${ }^{93} \mathrm{H}$. Arendt. The Human Condition (Chicago University Press 1958).

${ }^{94}$ N. Machiavelli, Discourses on Livy (H. Mansfield and N. Tarcov (eds.)) (University of Chicago Press 1998) p. 197.

${ }^{95}$ R. Bourke, 'What is Political Judgement?', in R. Bourke and R. Geuss (eds.), Political Judgement (Cambridge University Press 2009) p. 45. 
Similar concern for the need to leave space for creative and discretionary political judgement can also be found in the classic legal and natural law tradition - incidentally deeply influential in the drafting of the Irish Constitution. ${ }^{96}$ In this tradition, the concept of 'determination' is of critical importance to political action and authority. This concept proceeds on the premise that while public authorities are charged with securing the common good through the promulgation of legal ordinances, the precise form they must take, or content they must have, in order to secure this capacious end are not specified in detail by the natural law and thus must be given determinate content by political judgement in light of prudential and contextual considerations of a given political community. Thus, provided political authorities remain within the boundaries of the basic charge to promote the common good, there are typically countless ways to determine and give concrete effect to the general kinds of moral principles conducive to this end. ${ }^{97}$ As Finnis puts it, a determination is a kind of 'concretization of the general, a particularization yoking the rational necessity' of giving effect to broad principles of morality and justice necessary for realising the common good 'with a freedom (of the law-maker) to choose between alternative concretizations, a freedom which includes even elements of (in a benign sense) arbitrariness. ${ }^{98}$

These diverse intellectual traditions manifest, in practical politics, in the exercise of political judgement that is not entirely capricious or legally groundless, but also not directed or bound by legislative or juristic norms, and that allows for the exercise of prudential or discretionary judgement in the face of changing socio-political challenges as well as the novel and the unexpected. Ireland is a useful case study in how a culture of legalism in politics can diminish the sphere of political autonomy and undermine political actors' capacity and scope to make determinations and exercise discretionary judgement; how it can effect a serious degree of depoliticisation - the subjection of 'politics' to greater legal structure and constraint - even where formal judicial powers are in fact modestly deployed.

In the Irish impeachment episode and other case studies canvassed above, we see an aversion to the exercise of creative and discretionary political judgement, not on the grounds that it is legally unauthorised or lacking in legality as such, but rather because it calls for a form of judgement that occurs in a relative juristic

\footnotetext{
${ }^{96}$ D. Coffey, Drafting the Irish Constitution 1935-1937: Transnational Influences in Interwar Europe (Palgrave MacMillan 2018); G. Hogan, Origins of the Irish Constitution (Royal Irish Academy 2012).

${ }^{97}$ C. Casey, 'Common Good Constitutionalism' and the New Debate over Constitutional Interpretation in the United States', 4 Public Law (forthcoming, 2021).

${ }^{98}$ J. Finnis, 'Natural Law Theories', Stanford Encyclopaedia of Philosophy (2020), 〈https://plato. stanford.edu/entries/natural-law-theories/\#PurPosLawDetTheLegMorAutForCitJudFacMadReaForAct), visited 16 June 2021.
} 
vacuum, $-\mathrm{a}$ form of judgement that is authorised, but not directed or determined by law. This 'culture of legalism' is not directed against illegality or authoritarian power; but rather obscures the limits beyond which juristic rules or standards are no longer relevant or directly applicable. This culture is not merely concerned about the absence of legal constraint, but rather the absence of direction that usually arises from a legal norm or principle. It resists recognition that, at some point of statecraft, we encounter contingencies that require either the creation or revision, rather than the application of norms, or alternatively that require the application of non-normative - say prudential or contextual - modes of reasoning. ${ }^{99}$ The risk, as played out in the Irish context, is that such resistance might ossify aspects of the political order and seriously narrow the appropriate scope of political action for the common good. ${ }^{100}$

That being said, it would be misleading, to paraphrase Scheuerman, to frame this defence of autonomous political judgement as being tantamount to advocating a normative 'vacuum' or zones of unmediated power. ${ }^{101}$ Instead, what political constitutionalists at root argue for, and what traditions as diverse as the Machiavellian republican and natural law traditions attest the need for, is that polities ought to maintain ample space for autonomous political judgement precisely so they can better act in the service of compelling normative ends such as the public welfare or common good, in the face of the countless complexities and unexpected challenges facing the State.

This political sphere, the relatively autonomous zone of political judgement, might of course be threatened by rational bureaucracy in its Weberian sense, or by technocracy more generally - that is, by the specialisation of the administrative state apparatus and deference to it in the policymaking process by political actors who feel debilitated in second-guessing their advice and recommendations. ${ }^{102}$ Extensive or uncritical deference by the political branches to technocratic expertise threatens to erode political autonomy by creating an approach to politics which marginalises consideration of 'alternative views and solutions ... constraining public debate about an issue, freezing deliberation and locking-in certain policy directions ${ }^{103}$ as inevitable. It might also be

\footnotetext{
${ }^{99}$ As Galston puts the realist perspective: 'general principles, however valid, do not specify right answers to practical problems and, if taken literally as guides to practice, are apt to do more harm than good': W. Galston, 'Realism in Political Theory', 9 European Journal of Political Theory (2010) p. 385 at p. 396.

${ }^{100}$ Latham-Gambi, supra n. 80 , at p. 744.

${ }^{101} \mathrm{~W}$. Scheuerman, 'Carl Schmitt's Critique of Liberal Constitutionalism', 58 The Review of Politics (1996) p. 299 at p. 320-321.

${ }^{102}$ E.L. Windholz, 'Governing in a Pandemic: from Parliamentary Sovereignty to Autocratic Technocracy', 8 The Theory and Practice of Legislation (2020) p. 93.

${ }^{103}$ Ibid., at p. 107.
} 
threatened by the excessive normativism imposed by law, and specifically by the overreach of judicial powers - the canonical concern of political constitutionalism. ${ }^{104}$ What we have hoped to demonstrate in this article, however, is that it can equally be threatened, even under a legal system with large elements of political constitutionalism, by the symbolic power of the law at work in the sphere of politics itself.

${ }^{104}$ J.A.G. Griffith, 'The Political Constitution', 42 MLR (1979) p. 1 at p. 18-19; M. Tushnet, 'Policy Distortion and Democratic Deliberation: Comparative Illumination of the Countermajoritarian Difficulty', 94 Michigan Law Review (1995) p. 245 at p. 247. 